2016

\title{
Kinesthetic Language Learning: How an Accident Led to a Revelation
}

Travis West

Western Theological Seminary

Roger S. Nam

George Fox University, rnam@georgefox.edu

Amanda W. Benckhuysen

Calvin Theological Seminary

Follow this and additional works at: https://digitalcommons.georgefox.edu/gfes

Part of the Biblical Studies Commons

\section{Recommended Citation}

West, Travis; Nam, Roger S.; and Benckhuysen, Amanda W., "Kinesthetic Language Learning: How an Accident Led to a Revelation" (2016). Faculty Publications - Portland Seminary. 110.

https://digitalcommons.georgefox.edu/gfes/110 


\title{
Design \& Analysis
}

\section{Kinesthetic Language Learning: How an Accident Led to a Revelation}

\author{
Travis West, Western Theological Seminary \\ Roger S. Nam, George Fox Evangelical Seminary \\ Amanda W. Benckhuysen, Calvin Theological Seminary
}

\begin{abstract}
This essay analyzes a critical incident that took place in a hybrid distancelearning Hebrew language class that was adapting interactive, immersion-style, kinesthetic pedagogy during the week-long face-to-face intensive portion of the classincluding Total Physical Response techniques in which students respond to the language with whole-body actions, entering into the world created by the language and the particular biblical text. Memorization, performance, interactive games, songs, and skits also contribute to the immersion-style learning environment. A snafu on the final day of the week led to a serendipitous solution that demonstrated Parker Palmer's idea of subject centered pedagogy. A brief description and analysis of the critical incident is followed by two short responses.
\end{abstract}

\section{Kinesthetic Language Learning: How an Accident Led to a Revelation Travis West}

"Let there be light," I said, "And there was light." A student rose and placed a large piece of shimmering gold fabric onto the scene slowly forming in the center of the circle. I continued, "And God saw the light. . ." Pausing after the word "light," my eyes invited the students around the circle to respond, which they did, enthusiastically: "Indeed good!"

I continued to narrate the first four days of creation while students rose from their carpet squares around the circle to place the appropriate objects in the appropriate places at the appropriate times. What made this experience memorable was that students and teachers together told the story of Genesis 1 by rendering its vision of creation visually through a collective effort of synchronized narration and enactment. What made it remarkable was that the reenactment proceeded completely in Hebrew, at the halfway point of the first semester of a hybrid distance-learning Hebrew course.

\section{A Brief History}

I teach Hebrew and Old Testament at Western Theological Seminary in Holland, Michigan, a denominational seminary in the Reformed Church of America. Two semesters of both Greek and Hebrew are required for graduation in the MDiv program. In 2006 we transformed the in-residence Hebrew courses from a traditional grammar-translation method to an interactive, immersion-style, kinesthetic pedagogy. This pedagogy includes 
Total Physical Response (TPR) ${ }^{1}$ techniques in which students respond to the language with whole-body actions, entering into the world created by the language and the particular biblical text. Memorization, performance, interactive games, songs, and skits also contribute to the immersion-style learning environment.

The response to this class within the life of the seminary has been so overwhelmingly positive that in 2012 we began slowly integrating the interactive and oral-immersion pedagogy into our distance-learning Hebrew sequence. We wanted to bring the two courses into closer alignment, and to incorporate some of the formational components of the in-residence experience into the distance-learning format which had followed the more traditional grammar-translation approach. Our distance-learning cohorts consist of eighteen to twenty-five students, who range in age from their mid-twenties to mid-sixties. Most of these students are in full-time ministry.

Each semester distance-learning students come to campus for a face-to-face intensive that includes over twenty in-class hours over the course of five days. This week-long intensive comes at the halfway point of the first semester and sets the tone for the entire year by providing a number of opportunities for us to form a community as a class, and to encounter the biblical texts in their fullness.

The class is co-taught by a professor and an instructional assistant. One wall of the Hebrew classroom (yes, we have a designated classroom for Hebrew) is lined with large plastic bins overflowing with stuffed animals, plastic food, dolls, costumes, plastic weapons, and the like. We try in every way possible to make Hebrew a living language, letting the biblical texts come to life within the classroom, and within the heart of each student. A conservative guess would be that between 60-65 percent of every in-residence class and each week-long intensive class is conducted entirely in Hebrew.

\section{Subject-Centered Pedagogy}

Parker Palmer in The Courage to Teach talks about the importance of "subject-centered" teaching $(1998,116){ }^{2}$ For Palmer this has to do with both the structure of power in the classroom and the relation between students, teachers, and the subject matter. In a traditional classroom a clear hierarchy informs the relationship between the "expert" teacher and the "amateur" student (Palmer 1998, 100). The primary goal of the teacher is generally to "cover the field" by filling the heads of the students with as much information as possible, generally through lecture. ${ }^{3}$ In this de-centered classroom environment, the teacher is at the helm, controlling the students' learning (to the extent that is possible!). Students are generally passive participants, receiving information and regurgitating it on exams and in papers.

\footnotetext{
1 See Asher (2003) and for more information on TPR and Western Seminary's I-R Hebrew course, see Boelkins (2012).

2 The entire fifth chapter fleshes out Palmer's understanding of the meaning and implications of "a subject-centered education" (115-140).

3 Palmer makes it very clear, however, that the problem does not lie with presentation style; a lecture can be as effective as an experiential learning model. "Like teaching itself, creating educational community can never be reduced to technique. It emerges from a principle that can express itself in endless varieties, depending on the identity and integrity of the teacher" (Palmer 1998, 115-116). The important thing is to be explicit about learning goals and pedagogical values, and to find ways to create resonance between one's gifts as a teacher, the particularity of the subject matter, and the learning needs of the students.
} 
Palmer prefers a different approach. He explains this alternative, subject-centered approach to education by expanding on the opening line from "Auguries of Innocence" by William Blake: "To see a World in a Grain of Sand." He suggests that instead of the more typical pedagogical approach of "dumping truckloads of sand [information] on our students, blinding them to the whole," we would do well by simply "lifting up a grain so they can learn to see for themselves" (1998, 122; emphasis added).

Placing the subject at the center means giving up the power to dictate the conversation and control the learning process. To place the subject at the center means placing oneself on the periphery, along with the students, and together engaging the subject matter. In my context, the subject is the Hebrew language as it is used in various biblical texts to reveal something of the character of God and the character of the world God created and loves.

Because form forms (the shape of the classroom shapes the learning that happens there), we physically arrange our classroom to reflect this subject-centered approach by removing desks and tables from the classroom and setting the chairs in a broad semicircle with a large open space in the middle for interactive exercises, skits, songs, and so forth.

And because my theories are always closer to the truth than my practices, I generally receive it as a gift when I experience theory and practice coming together in a profound way that leaves a deep impression on me and on my students. I had this experience on the fifth and final day of a recent distance-learning intensive.

\section{Centering on Genesis 1}

Before I describe the final day, I must introduce an aspect of the first four days. The primary biblical text we engaged throughout the week was Genesis 1. My co-teacher, Pam Qiqayon, and I carefully introduced the meaning of the words in the passage. For example, to teach הבדיל ("to separate/divide") we poured all of our stuffed animals out on the floor and had the students divide between "clean" and "unclean" animals, or divide between the male and female dolls, and so forth. To teach תהו ובהו "fformless and empty") we threw around a tangled mess of rope; scribbled all over the white board; and generally flailed arms, body, and legs to get across the idea of chaos, lack of form, and a substance without borders, shape, or purpose. To teach שמים ("heavens"), פרי עץ ("fruit tree"), דשא ("grass"), עשב ("green plant"), and many other words, we left the classroom and walked outside to engage the realities the words point to directly (which may or may not have involved planting several different types of plastic fruits into the branches of a small pine tree). Each day, after introducing the relevant vocabulary, I would recite that portion of Genesis 1 while Pam demonstrated the actions and words with the same gestures and props we had just used to teach them.

Then came the last day of class. We had intended to spend thirty minutes before the final afternoon session setting up an elaborate display to enact the full text of Genesis 1 for our students. It was going to involve music stands, binder clips, and several layers of fabric replete with strategically placed packets of seeds, fruit trees, fish, birds, animals, and so forth. Each movement in the story would peel back another layer of fabric, revealing the next stage of creation. We were going to offer it as a gift to them after spending so much time in the passage throughout the week.

Unfortunately, Pam and I both overlooked one minor detail: the final session started thirty minutes earlier than the previous afternoon sessions. Thus, we showed up to class just as it should have been starting. We had to make a split-second decision. There was no 
way we could set up our gift presentation. Pam, always quick on her feet, came up with a plan that was more brilliant than either of us realized at the time.

\section{An Accidental Gift}

She went to our carpet square bin and handed one to each student, telling them to sit in a circle on the floor. She then dumped all of the objects we had used throughout the week to illustrate Genesis 1 into the center of the circle of carpet squares. She instructed the students to divide all of the objects evenly among themselves. I would slowly recite the text, leaving pauses for them to fill in the words they could remember. At the same time, students would add their objects to the illustration of the developing story in the middle of the circle.

Sitting in the circle, watching the story unfold, I could not help but think about Parker Palmer's subject-centered pedagogy. This "accident" was a parable of transformational teaching happening right in front of our eyes. Everyone was fully engaged. No one passively waited for their turn to place an object. They worked together; each student helped their neighbor remember the words and cues. I narrated the story, but we all told it together. In that moment, the subject was truly at the center - literally and figuratively. Theory was realized in practice.

When evening and morning had passed on the fourth day, we all sat in hushed silence, taking in the gift we had just received. Pam knew that the window was short before I would begin to unpack the story and help the students see what I thought about what had just happened, so she asked the students a simple question first: "What did you see?" Without a moment's hesitation one student responded, "I see myself." When I prompted him to say more, he continued, "Into the messiness, the chaos, the tohu vavohu of my life God's word speaks and creates order and purpose and space in which life can flourish." That vulnerable and exegetically insightful comment set the tone for the entire conversation that ensued. If I had started the conversation by walking through the story and explaining a variety of exegetically and theologically important ideas, the students would have appreciated it and it would have been delightful I am sure. But, it would have made the discussion a response to what I thought was important, instead of what the students saw in the text and thought was important. I would have been dictating the conversation instead of the subject. Pam knew this instinctively and prevented me from accidentally hijacking the conversation. The result was a conversation that was lively, ranging from personal insights to grammatical issues. It even moved toward exploring places of resonance between science and faith. The experience was a remarkable gift, a perfectly "accidental" way to conclude our intensive together.

I called this experience a parable because it illustrates for me a number of truths.

- Subject-centered pedagogy creates space for students to be agents in their own learning. I teach in a seminary context with adult learners who have been deeply shaped by the contemporary educational system in the West, which does not generally promote agency, but rather passivity. When students are given agency to influence the learning process, the classroom environment changes and new possibilities arise for both teachers and students to be transformed.

- Sometimes our most profound experiences as teachers happen accidentally. This reality helps keep us humble. It also reminds us that, even when our best-laid plans fall apart, the values embedded in the course express themselves - sometimes more powerfully than we could have planned.

- Team teaching is generative. Left to my own devices I would not have created the space for that experience to unfold in the way that it did. It was the mutual trust built between 
Pam and me over several years of teaching together that allowed me to follow Pam's instincts without hesitation as she started whipping out carpet squares ten minutes after class started.

\section{On Second Language Acquisition Immersion pedagogies: Response to Travis West's "Kinesthetic Language Learning" Roger S. Nam}

This innovative in-class exercise is commendable with its embodied learning approach based on Second Language Acquisition (hereafter, SLA) immersion pedagogies as an alternative to the traditional grammatical approaches that have dominated ancient language learning. Greek, Hebrew, and Aramaic pedagogies need to move away from total reliance on such traditional approaches, as today's seminary student is statistically older, more anxious over languages, and less likely to take an ordination exam requiring original language proficiency.

I affirm the inventive spirit and this example of kinesthetic learning that goes beyond grammar lecture, exercises, quiz, repeat. But I do have several concerns over West's approach, perhaps partially due to my ignorance of the greater context of the class. First, although the described learning environment is certainly more fun and livelier than a traditional language classroom, I wonder about the long-term retention of such an approach. As I understand, SLA research suggests that the success of language immersion requires many hours of actual immersion. Although I see this as plausible for a traditional face-to-face class, by design, the described hybrid-intensive setting cannot reach the requisite hours needed to substantively contribute to reading competency. Supplementary materials would need to reinforce any classroom SLA techniques to develop long-term habits and accessible tools to yield a higher access to biblical texts in their original languages. With the quoted example, of tohu vavohu, I am not quite convinced that the animated exercise by itself can bring the student to a deeper appreciation of this cryptic Hebrew phrase beyond what is accessible in an English translation. Alternatively, I wonder if the utilization of accessible technological tools, like Accordance on a smart phone, and a simple context search for the word tohu and its nineteen appearances in the Hebrew Bible, would yield a more critical understanding of such a phrase.

Second, although I am intrigued with the possibilities of an immersion approach, I would also stress a general caution in applying SLA techniques to ancient language acquisition within a theological context. Much of the research in SLA is conducted with school-age children, who have vastly heightened capacities for learning second languages when compared to adult students. In seminary contexts, many adult learners approach language learning with trepidation based on unsuccessful prior experiences. One study shows that seminarians over forty face significantly greater challenges in ancient language acquisition (Baker 1998, 171). I can see potential in immersion strategies, but it must be taught within an awareness of the distinction of studying a dead language with its different goals. Seminary language instructors do not strive towards conversational fluency, but rather reading competencies. As products of an elite literati, the language of biblical texts elude the communicative conventions of speech, which are a fundamental centerpiece of SLA research. Subject-centered approaches would do well to remember this in their course designs and execution, whether accidental or not. 


\section{A Truly Great Thing: Response to Travis West's "Kinesthetic Language Learning" Amanda W. Benckhuysen}

This is what I want for my students. That was my gut reaction to Travis West's vivid account of his Hebrew class and the "accidental insight" that generated such robust engagement with the biblical text. I want for my students not just knowledge, but wisdom the ability to make connections to their own life and to integrate their newfound knowledge into their efforts at making sense of the world. The question is, how does one create the conditions which make such moments of insight possible for our students? How does one shape the classroom experience so that it is a ripe and generative environment for student learning? West highlights team teaching, subject-centered pedagogy, and student agency as factors which contributed to the success of this classroom experience, strategies which do seem especially promising. Yet an additional factor deserves mention here - clear discernment and identification of the subject matter.

Let me explain. At first glance, the subject matter for any given course may seem selfevident: it is the topic or content that the instructor determines to teach. The example of biblical Hebrew, however, highlights the potential challenges and complexities in adequately defining the subject matter. For many who teach biblical Hebrew, particularly those who teach in theological schools that train persons for ministry, facility with the language is not an end in itself. Instead, it is a means to an end, a way into the biblical text and the world of the ancient Israelites. Instructors of biblical Hebrew often find it difficult, however, to reflect this in their courses, struggling with how much and what parts of Hebrew grammar students need to know to read the biblical text well. It is not uncommon for courses in biblical Hebrew to over-teach the minutiae of Hebrew grammar, using biblical texts only to illustrate grammatical concepts while endlessly deferring any sustained exegetical reflection on them. The result for many students taking biblical Hebrew in theological schools is a profound disconnect between the course material and their own educational and vocational goals. It is this disconnect which invites us to reflect more deeply on what we hope students get out of Hebrew language classes and how it contributes to their formation for ministry. One lens through which to engage in such reflection is to consider how we understand and identify the subject matter.

In his discussion of subject-centered teaching, Parker Palmer describes subjects as the great things of the universe around which seekers have always gathered, and which continue to beckon us deeper into the exploration of their mysteries and their truth (1998, 109-110). Given this definition, what, then, is the subject matter of biblical Hebrew, the great thing around which the community of learners gathers? One strong candidate is West's own description, which shifts the focus from Hebrew grammar to God's self-revelation through the biblical text. ${ }^{4}$ Here, language proficiency is relegated to its proper place as a tool, the means by which students open themselves up to the truly great thing which now stands at the center of the classroom. The impact of this shift on West's classroom is unmistakable. "What did you see?" Pam asked, moving the students beyond the mechanics of the words deeper into the heart of the text. "I see myself," the student responded. "Into the messiness, the chaos, the tohu vavohu of my life, God's word speaks and creates order and purpose and space in which life can flourish." Perhaps if our students

\footnotetext{
4 West describes the subject matter as "the Hebrew language as it is used in various biblical texts to reveal something of the character of God and the character of the world God created and loves."
} 
experience more of these "accidental insights," they may come to see learning biblical

Hebrew not only as a degree requirement, but as a vital part of their theological formation.

\section{Bibliography}

Asher, James J. 2003. Learning Another Language Through Actions. Los Gatos, Calif.: Sky Oaks Productions.

Baker, David. 1998. "Studying the Original Texts: Effective Learning and Teaching of Biblical Hebrew." In Make the Old Testament Live: From Curriculum to Classroom, edited by R. Hess and G. Wenham, 161-171. Grand Rapids, Mich.: Eerdmans.

Buth, Randall. Biblical Language Center. http://www.biblicallanguagecenter.com/products/ (accessed July 2016).

Boelkins, Dawn. 2012. A Variety of Gifts: Theological and Pedagogical Inquiry on the Teaching of Biblical Languages. DMin dissertation. Holland, Mich.: Western Theological Seminary.

Gravett, Sandra L., Ulrich, Daniel W., Nysse, Richard W., Polaski, Sandra Hack. 2011. "Forum: Teaching Biblical Studies Online" Teaching Theology and Religion 14, no. 3: 256-283.

Harlow, Joel. 2007. "Successfully Teaching Biblical Languages Online at the Seminary Level: Guiding Principles of Course Design and Delivery." Teaching Theology and Religion 10, no. 1: 13-24.

Jacobson, Rolf. 2011. "Learning Hebrew by Writing in English.” Teaching Theology and Religion 14, no. 2: 125-136.

Morse, MaryKate. 2004. "Enhancing the Learning and Retention of Biblical Languages for Adult Students." Teaching Theology and Religion 7, no. 1: 45-50.

Overland, Paul. 2004. "Can Communicative Methods Enhance Ancient Language Acquisition?" Teaching Theology and Religion 7, no. 1: 51-57.

Palmer, Parker J. 1998. The Courage to Teach: Exploring the Inner Landscape of a Teacher's Life. San Francisco, Calif.: Jossey-Bass. 